\title{
Zooplankton Biomass Variability in the Mexican Eastern Tropical Pacific ${ }^{1}$
}

\author{
Carmen Franco-Gordo, ${ }^{2}$ Enrique Godínez-Dominguez, ${ }^{2}$ and Eduardo Suárez-Morales ${ }^{3}$
}

\begin{abstract}
The time and space distribution of zooplankton biomass recorded during a year cycle (December 1995-1996) off the Pacific coast of central México is analyzed. Samples were obtained by surface $(42-86 \mathrm{~m})$ oblique hauls at 12 sampling sites using a Bongo net. The overall average displacement volume biomass of zooplankton during the surveyed period was $1138 \mathrm{~cm}^{3} /$ $1000 \mathrm{~m}^{3}$. Principal component analysis indicated that highest biomass concentrations occurred at coastal stations. The months with highest biomass values were those in which the lowest sea surface temperature values occurred (January-May). This was the same period in which the California Current was strongest and clearly influenced the hydrological conditions of the surveyed area. In these months, advective processes are active along the outer shelf, favoring upwelling of colder, relatively nutrient-richer waters that promote an overall local increase of zooplankton activity and populations. The high variability of biomass values is indicative of episodic, localized processes that enhance productivity in the area.
\end{abstract}

Resumen: Se analiza la distribución espacial y temporal de la biomasa zooplánctica obtenida durante 11 meses en las costas de Jalisco y Colima, en el Pacífico Central Mexicano, desde diciembre de 1995 a diciembre de 1996. Las muestras fueron obtenidas por arrastres doble oblicuos en 12 estaciones, con una red bongo con mangas de $0.333 \mathrm{~mm}$ y $0.505 \mathrm{~mm}$, y una profundidad de arrastre entre los 42 y $86 \mathrm{~m}$. En este estudio sólo se analiza la malla de $0.505 \mathrm{~mm}$. El valor medio de la biomasa obtenido para todo el periodo fue de $1138 \mathrm{~cm}^{3}$ estandarizado a $1000 \mathrm{~m}^{3}$. A través del análisis de componentes principales, se observó que las mayores concentraciones de biomasa estuvieron en las estaciones cercanas de la costa, y el periodo de mayores concentraciones coincide con los valores más bajos de temperatura, bajo la influencia de la Corriente de California (Enero-Mayo). Durante ese periodo el área de estudio se encuentra bajo la influencia de procesos advectivos, lo que propicia afloramientos de aguas profundas más frías y ricas en nutrientes. La alta variabilidad mostrada por los datos indica que los procesos que controlan los incrementos de la productividad son episódicos y locales.

\footnotetext{
${ }^{1}$ Manuscript accepted 16 August 2000.

2 Centro de Ecología Costera, Universidad de Guadalajara, Gómez Farías no. 82 San Patricio-Melaque, Jalisco CP 48980, México. Current address: Universidad de La Coruña, Departamento de Biología Animal, Vegetal, y Ecología, Campus Zapateira s/n, La Coruña, España 15071 (cfranco@mail2.udc.es).

${ }^{3} \mathrm{El}$ Colegio de la Frontera Sur (ECOSUR), Zona Industrial No. 2 Carretera Chetumal-Bacalar, A.P. 424, Chetumal, Quintana Roo 77000, México.
}

Pacific Science (2001), vol. 55, no. 2:191-202

(C) 2001 by University of Hawai'i Press.

All rights reserved
The zooplankTon community represents a relevant link that transfers energy from primary producers to higher trophic levels in pelagic trophic webs (Baduini 1997). The patterns of distribution and abundance of zooplankton are affected by physical phenomena on very different spatial scales (Haury et al. 1978, Denman and Powell 1984). Physical factors include hydrographic events such as currents, wind stress, eddies, and upwelling and stratification of the water column (Haury et al. 1978, Owen 1981).

One of the parameters most frequently 
used to evaluate the overall activity and density of this community is the measurement of biomass (Beers 1981). Seasonality and production cycles of zooplankton exhibit geographical variations and are determined by the availability of nutrients, hydrological conditions, and the dynamics of the zooplankton/phytoplankton interactions (Heinrich 1962, Baduini 1997). Hence, the understanding of coupling of physical oceanic processes and zooplankton dynamics on a seasonal basis has been attempted in different areas of the Pacific Ocean but mainly in the California Current system (Chelton et al. 1982, Roesler and Chelton 1987, McGowan et al. 1996, Lavaniegos et al. 1998). The tropical area of the Mexican Pacific has received little attention, and basic information on the zooplankton community is scarce.

Our study analyzed the space and time distributions of the neritic zooplankton biomass off the Pacific coast of central México to describe its dynamics and assess the influence of the seasonal coastal current pattern, advective processes, and other hydrological conditions.

\section{MATERIALS AND METHODS}

The survey area comprises a fringe along and over the continental shelf stretching from Punta Farallón in the state of Jalisco $\left(19^{\circ} 19^{\prime} 77^{\prime \prime} \mathrm{N}, 105^{\circ} 00^{\prime} 28^{\prime \prime} \mathrm{W}\right)$ to Cuyutlán, state of Colima $\left(18^{\circ} 58^{\prime} 24^{\prime \prime} \mathrm{N}\right.$, $\left.104^{\circ} 13^{\prime} 51^{\prime \prime} \mathrm{W}\right)$ (Figure 1). The coastline is irregular and includes several bays: Tenacatita, Navidad, and the coastal complex Santiago-Manzanillo. The remainder of the coast is formed by relatively extensive, open beaches (Godínez-Domínguez and GonzálezSansón 1998). The hydrological dynamics in the area is dominated by a northwestward flow during summertime and a southwestward flow during winter (Pacheco-Sandoval 1991, Badan 1997). In winter and spring the area is strongly influenced by water and conditions set by the California Current (CC). In summer and autumn the CC weakens and the area is then influenced by the flow of tropical water from the North Equatorial Counter- current (NECc) (Pacheco-Sandoval 1991, Filonov et al. 2000).

The oceanographic sampling plan included 12 sites, distributed as shown in Figure 1. Zooplankton hauls were performed monthly during nighttime (2000-0700 hours) from December 1995 to December 1996. To avoid the considerable influence that smallscale hydrographic variability may have on the interpretation of overall larval dispersal (Smith et al. 1999), all trawls for a month were carried out during one night. Hauls were all oblique, at depths varying from 42 to $86 \mathrm{~m}$. A standard Bongo net with 0.33- and $0.5-\mathrm{mm}$ meshes and $0.6-\mathrm{m}$ mouth diameter was used. A digital flowmeter was adapted to the mouth of the $0.5-\mathrm{mm}$ net to estimate the amount of water filtered by this gear (Smith and Richardson 1979). Zooplankton samples were fixed and preserved in a $4 \%$ formalin solution, which was buffered later with sodium borate (Griffiths et al. 1976). Because of adverse climatic conditions, sampling was not possible during August and September 1996. Sea surface temperature (SST) and salinity were measured at each sampling site using a Seabird SBE19 CTD profiler.

Samples collected in the $0.5-\mathrm{mm}$ net were processed immediately to obtain the zooplankton biomass to avoid volume changes associated with long-term preservation (Ahlstrom and Thrailkill 1963). Samples were processed according to the displacement volume method (Beers 1976). Organisms measuring over $3 \mathrm{~cm}$ in length were excluded from the samples; gelatinous zooplankters below this size were included in the biomass estimations. Estimated biomass values are reported as $\mathrm{cm}^{3}$ per $1000 \mathrm{~m}^{3}$ of filtered water.

Month-to-month variations in biomass were analyzed for all of the sampling sites. The monthly biomass values were averaged and a confidence range established according to Zar (1996). Month-to-month differences along the coast-oceanic gradient were evaluated using a Friedman variance analysis (Zar 1996). This method of analysis was selected because the distribution of biomass values in the area was not considered to be statistically normal. To determine the relation between zooplankton biomass values, temperature, 


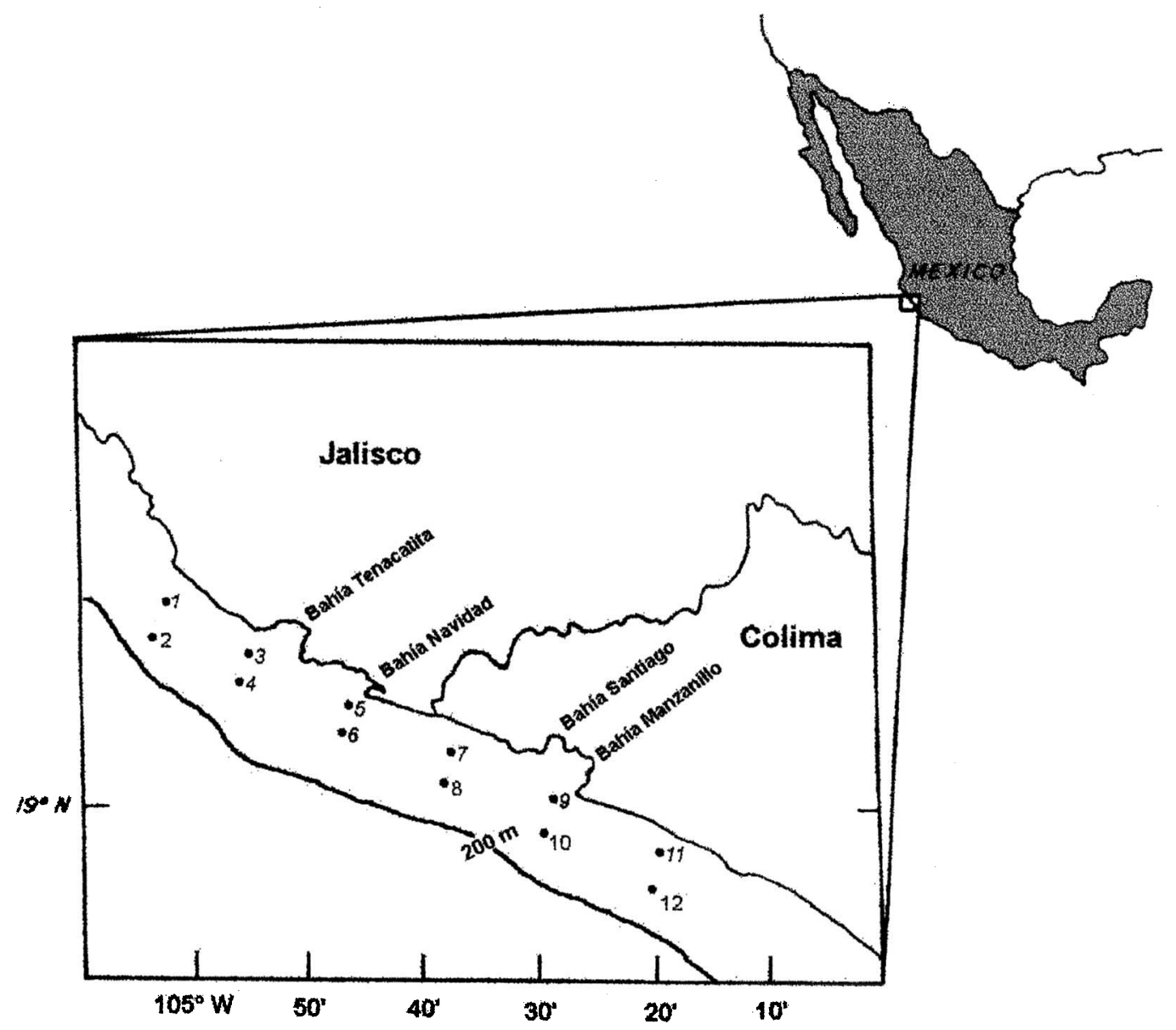

FIGURE 1. Survey area showing location of sampling stations off the coast of Jalisco and Colima, México.

and salinity, standard correlation tests were used. A principal component analysis (PCA) was performed using biomass values from each sampling site and month (log data transformed). This was done to determine time/space distributional patterns of zooplankton biomass in the surveyed area.

\section{RESULTS}

Monthly differences in zooplankton biomass during the survey period were statistically significant $\left(X^{2}=76.24, \quad n=12, \quad \mathrm{df}=10\right.$, $P<0.005)$. The highest biomass values were recorded during January, March, April, and
May. Biomass decreased in June and July and began to increase again in December (Figure $2 a)$. The wide variation of confidence ranges indicates a high heterogeneity of biomass values throughout this period. Zooplankton biomass showed a significant tendency to decrease offshoreward $\left(X^{2}=13.63, n=66\right.$, $\mathrm{df}=1, P<0.005)$. Maximum concentrations were recorded at stations near the coast (Figure $2 b$ ), which were also the shallowest (Table 1).

The ordination method used allowed verification of the differential behavior of zooplankton biomass values. The first component included the $68.5 \%$ of the variance in 


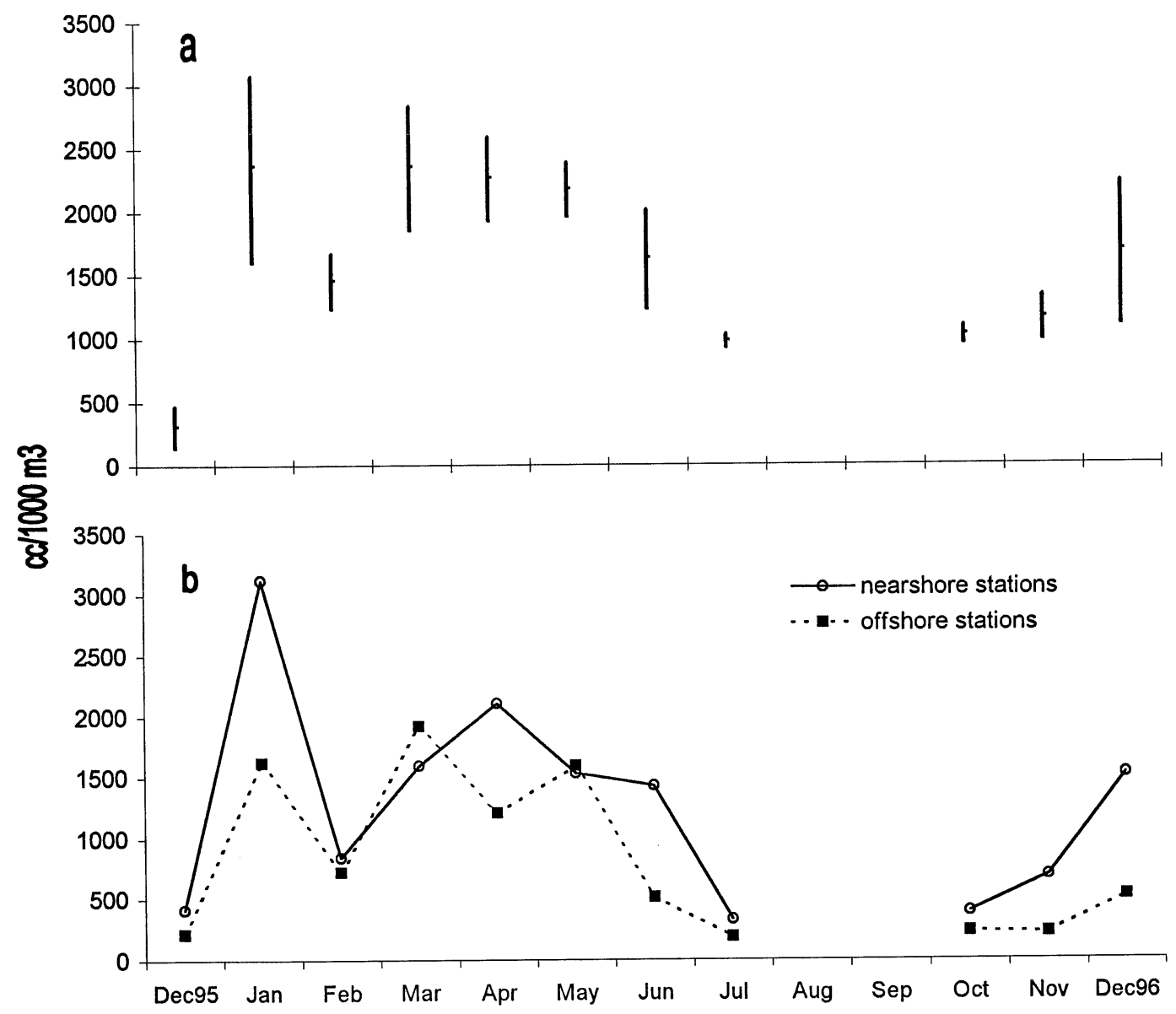

FIGURE 2. Monthly biomass distribution (a) mean and $95 \% \mathrm{CI}$ and $(b)$ in relation to coast proximity.

TABLE 1

Depth Characteristics of Sampling Sites (See Figure 1)

\begin{tabular}{rccccc}
\hline \hline Sites & Latitude & Longitude & $\begin{array}{c}\text { Depth } \\
\text { Bottom (m) }\end{array}$ & $\begin{array}{c}\text { Depth } \\
\text { Trawl (m) }\end{array}$ & $\begin{array}{c}\text { \% Sampled } \\
\text { Water Column }\end{array}$ \\
\hline 1 & $19^{\circ} 16^{\prime} 645^{\prime \prime} \mathrm{N}$ & $104^{\circ} 55^{\prime} 765^{\prime \prime} \mathrm{W}$ & 60.0 & 44.7 & 74.5 \\
2 & $19^{\circ} 15^{\prime} 898^{\prime \prime} \mathrm{N}$ & $104^{\circ} 56^{\prime} 216^{\prime \prime} \mathrm{W}$ & 126.0 & 77.2 & 61.2 \\
3 & $19^{\circ} 14^{\prime} 173^{\prime \prime} \mathrm{N}$ & $104^{\circ} 51^{\prime} 206^{\prime \prime} \mathrm{W}$ & 60.9 & 44.7 & 73.3 \\
4 & $19^{\circ} 13^{\prime} 086^{\prime \prime} \mathrm{N}$ & $104^{\circ} 52^{\prime} 922^{\prime \prime} \mathrm{W}$ & 94.8 & 64.1 & 87.6 \\
5 & $19^{\circ} 10^{\prime} 744^{\prime \prime} \mathrm{N}$ & $104^{\circ} 44^{\prime} 022^{\prime \prime} \mathrm{W}$ & 60.0 & 48.0 & 91.3 \\
6 & $19^{\circ} 09^{\prime} 398^{\prime \prime} \mathrm{N}$ & $104^{\circ} 32^{\prime} 657^{\prime \prime} \mathrm{W}$ & 93.0 & 85.0 & 65.8 \\
7 & $19^{\circ} 07^{\prime} 215^{\prime \prime} \mathrm{N}$ & $104^{\circ} 31^{\prime} 855^{\prime \prime} \mathrm{W}$ & 60.4 & 44.0 & 71.4 \\
8 & $19^{\circ} 06^{\prime} 163^{\prime \prime} \mathrm{N}$ & $104^{\circ} 32^{\prime} 343^{\prime \prime} \mathrm{W}$ & 120.9 & 79.4 & 62.9 \\
9 & $19^{\circ} 01^{\prime} 653^{\prime \prime} \mathrm{N}$ & $104^{\circ} 20^{\prime} 839^{\prime \prime} \mathrm{W}$ & 61.0 & 43.6 & 69.6 \\
10 & $19^{\circ} 00^{\prime} 547^{\prime \prime} \mathrm{N}$ & $104^{\circ} 21^{\prime} 213^{\prime \prime} \mathrm{W}$ & 96.5 & 60.7 & 65.4 \\
11 & $18^{\circ} 59^{\prime} 647^{\prime \prime} \mathrm{N}$ & $104^{\circ} 17^{\prime} 809^{\prime \prime} \mathrm{W}$ & 60.3 & 42.0 & 86.8 \\
12 & $18^{\circ} 58^{\prime} 577^{\prime \prime} \mathrm{N}$ & $104^{\circ} 18^{\prime} 817^{\prime \prime} \mathrm{W}$ & 132.7 & & \\
\hline
\end{tabular}



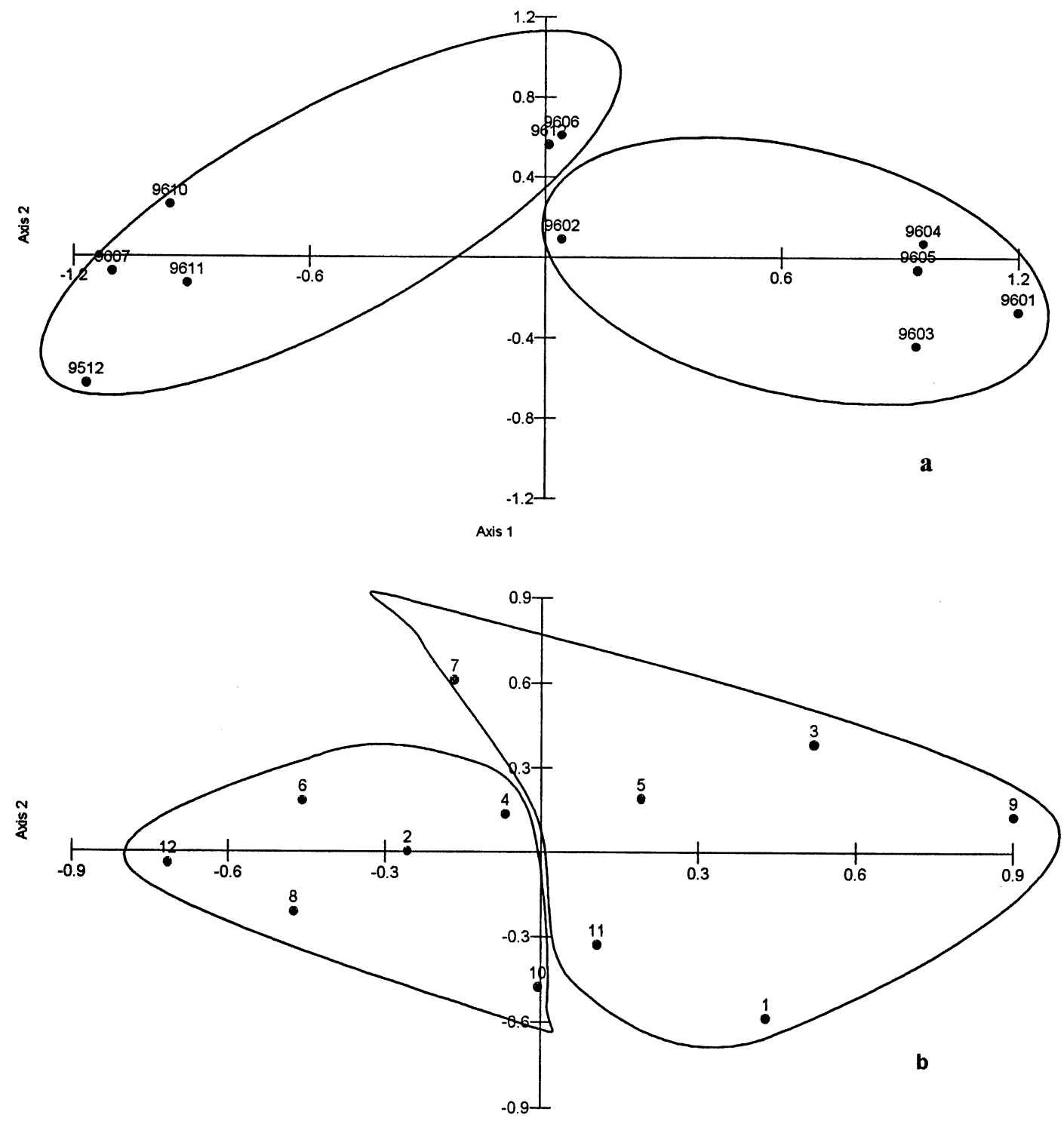

Axis 1

Figure 3. Principal component analysis of (a) sampling months (codes refer to year and month) and $(b)$ station sampling (even numbers denote offshore stations; odd numbers denote nearshore stations).

data and the second, the $78.9 \%$ of the accumulated variance. Two distinct clusters were defined, the first one included winter and spring months (January-May), and the second one contained June-December (Figure 3a). February, June, and December 1996 were located close to the origin between both clusters. June and December probably represent the transition time between two hydroclimatic periods (end and onset of the NECc and CC). These transitional periods could vary between years, and one example of that 
is the difference in biomass values in two December months (1995 and 1996). February was the month with highest zooplankton biomass values and the highest variance. The PCA yielded two station groups: the first one (odd numbers) represented the near-shore sampling sites, whereas the second included off-coast stations (Figure $3 b$ ). The first component could be interpreted in both cases (months and stations) as hydrodynamic variability associated with the coastal current pattern.

A significant and inverse relationship $(r=-0.61, P<0.005)$ was found between biomass and temperature at $10 \mathrm{~m}$ depth (Figure $4 a$ ). Salinity and zooplankton biomass were also significantly correlated, but less strongly $(r=0.38)$ (Figure $4 b)$. Salinity and temperature of water at $10 \mathrm{~m}$ varied throughout the survey period (Figure 5). Salinity exhibited relatively stable behavior between December 1995 and June 1996, with monthly average values ranging from 34.2 to 34.7 psu. Salinity decreased during the rainy season, with a minimum (33.4 psu) in October. Water temperature was lowest from January to May; March was the coldest month $\left(21.4^{\circ} \mathrm{C}\right)$. Another thermic period was characterized by higher mean temperatures $(26.3$ to $29.2^{\circ} \mathrm{C}$ ) and included summer and autumn.

Temperature profiles (Figure 6) during July were representative of tropical oceanographic conditions, with warm surface waters $\left(29.7^{\circ} \mathrm{C} \mathrm{SST}\right)$ and a strong stratification with a deep thermocline. Contrasting temperature profiles from March 1996 featured a thicker mixing layer and lower $\operatorname{SST}\left(22.2^{\circ} \mathrm{C}\right)$, which are conditions related to the influence of the CC. During this season, coastal upwelling is produced by wind stress from the northwest that displaces water offshore and replaces it with nutrient-rich, cold water, from greater depths. The December profile is indicative of the end of the tropical season in the area, during which the influence of the NECc weakens and the progressive invasion of the CC is more evident (see Wyrtki 1965). The end of the influence of the CC in the area is indicated by the thermic profile from May, with the thermocline going deeper and with increasing SST values.

\section{DISCUSSION}

Our data represent the first information on the month-to-month variation of zooplankton biomass during a year cycle in the coastal area of the Mexican tropical Pacific. Biomass values showed a sharp two-season pattern during the survey period. Maximum average biomass values were recorded in the first season, between January and June. The second season featured relatively low mean biomass figures and included the JulyDecember period. A seasonal pattern of zooplankton productivity along the CC system has been recognized by several authors (Chelton et al. 1982, Roesler and Chelton 1987). Based on the analysis of a long-term series of zooplankton surveys in the centralwestern part of the Baja California peninsula, Lavaniegos et al. (1998) found highest biomass concentrations during summer (June through October). In general, the northern portion of the Gulf of California has a nearly continuous high productivity level, the western coastal edge of the peninsula shows higher values during spring, and the eastern coast has increased biomass values in the autumn (Tunell et al. 1996). These subtropical-temperate patterns are expected to vary as one approaches lower, tropical latitudes, where biomass variations tend to be less pronounced (Suárez-Morales and Gasca 1994). In the oceanic region known as the North Equatorial Countercurrent Province of the Pacific, located off the coast of the Mexican section of the eastern tropical Pacific (see Longhurst 1998), two peaks of secondary production have been recognized. The first peak occurs in winter (December-April or May), and the second in summer. This pattern has been observed for the southern part of Baja California, where Hernández-Trujillo (1998) found the highest average values during winter and spring (over $250 \mathrm{~cm}^{3} / 1000 \mathrm{~m}^{3}$ ) and lowest in summer and autumn (below $\left.200 \mathrm{~cm}^{3} / 1000 \mathrm{~m}^{3}\right)$. This area is considered to be a transitional zone, but is still strongly influenced by tropical conditions. The pattern described by Hernández-Trujillo (1998) is consistent with the tendency shown by our biomass data throughout the year cycle. 

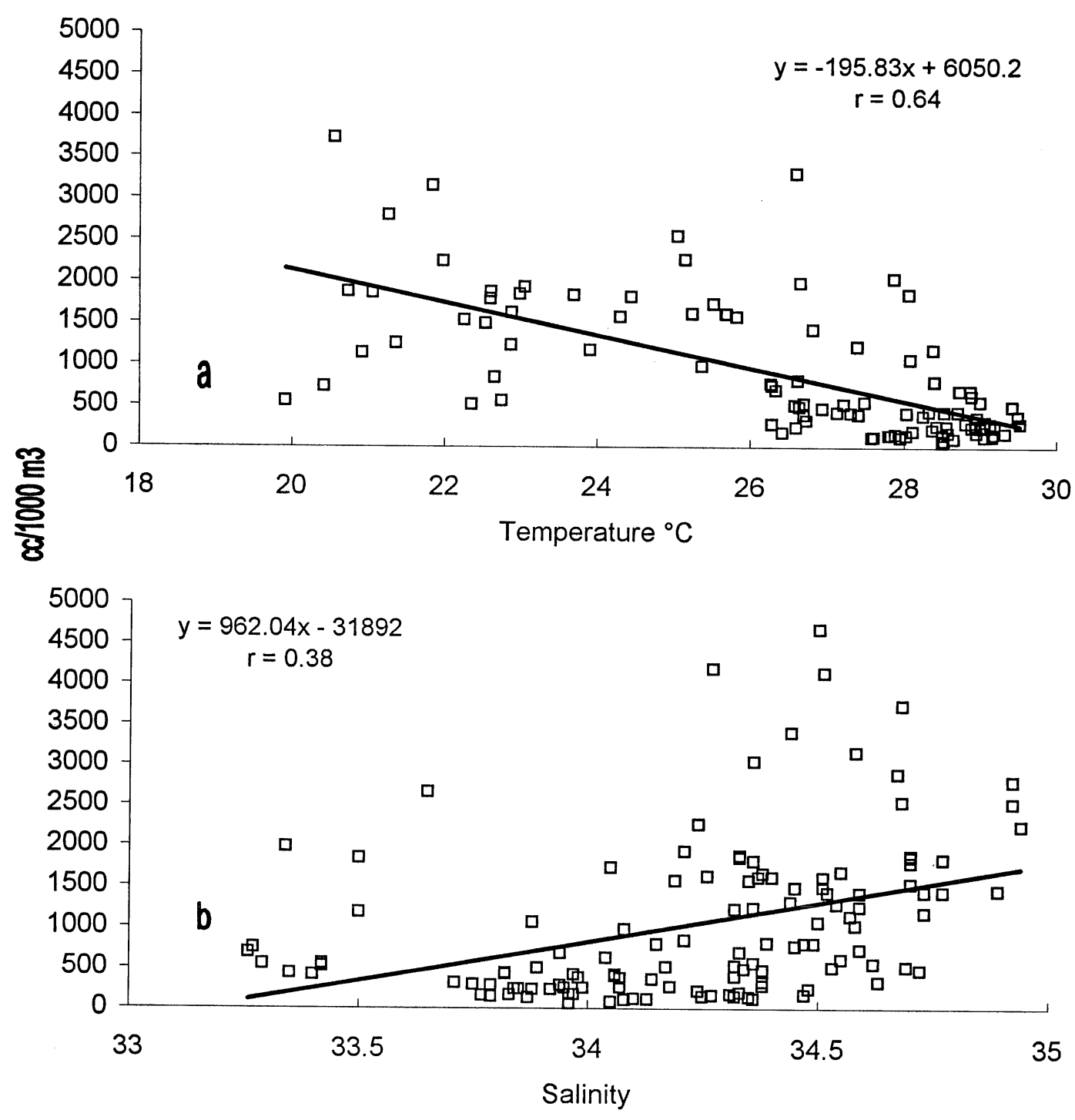

FIGURE 4. Relationship between biomass $\left(\mathrm{cm}^{3} / 1000 \mathrm{~m}^{3}\right)$ and sea water temperature $(a)$ and salinity $(b)$.

The average zooplankton biomass recorded in the surveyed area was about four times higher than that reported by Hernández-Trujillo (1998) in the southern part of Baja California $\left(240 \mathrm{~cm}^{3} / 1000 \mathrm{~m}^{3}\right)$. His highest values at $21^{\circ} \mathrm{N}$ are about $357 \mathrm{~cm}^{3} /$ $1000 \mathrm{~m}^{3}$. McGowan et al. (1996) studied the long-term mean zooplankton biomass along the $\mathrm{CC}$, and they reported most values as ranging between 200 and $800 \mathrm{~cm}^{3} / 1000 \mathrm{~m}^{3}$.
Our values are comparable to those reported by Brinton et al. (1986) (about $1024 \mathrm{~cm}^{3}$ / $1000 \mathrm{~m}^{3}$ ) in the productive coastal areas of the Gulf of California, and by Jiménez-Pérez and Lara-Lara (1988) in the central Gulf of California $\left(988 \mathrm{~cm}^{3} / 1000 \mathrm{~m}^{3}\right)$. Hence, the coastal areas of Colima and Jalisco have moderate to very high zooplankton biomass values, probably because of short-term, local events, as explained below. 


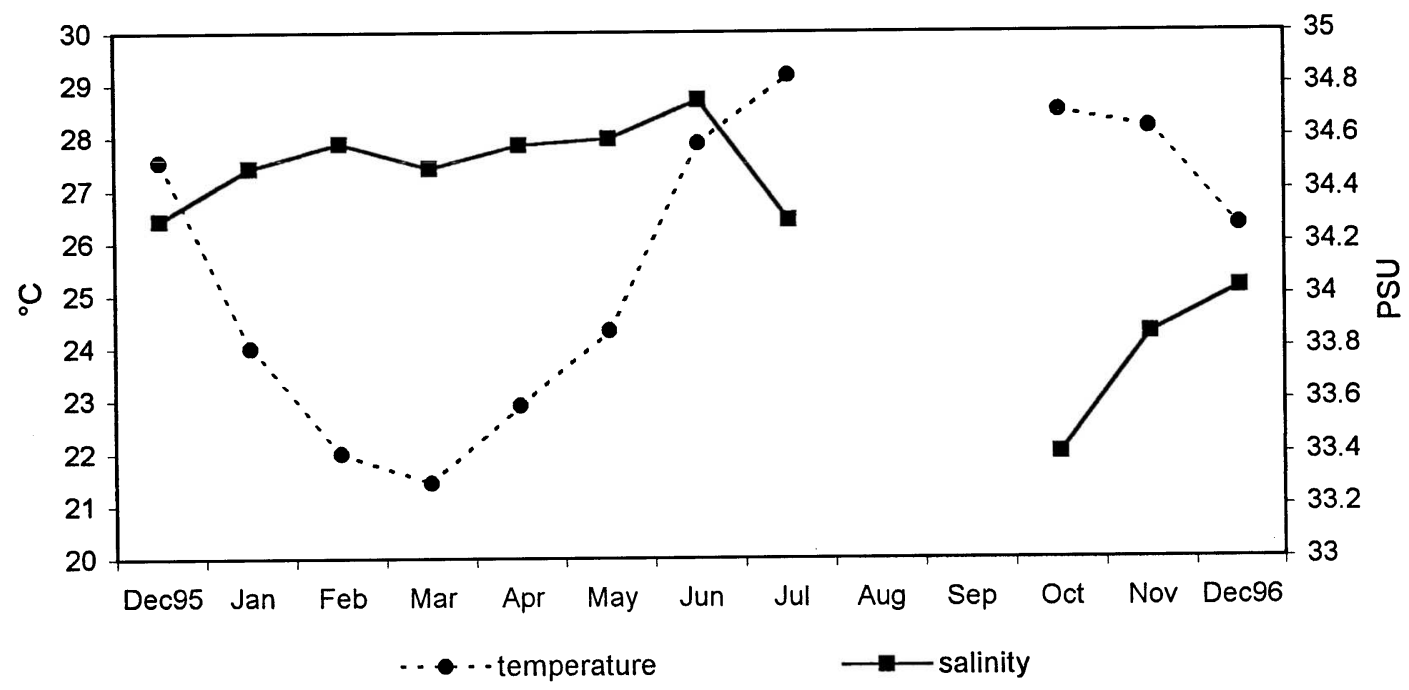

FIgURE 5. Temperature and salinity monthly averages recorded at $10 \mathrm{~m}$ depth.

The inverse behavior exhibited by zooplankton biomass concentrations and temperature values agrees with several earlier reports (Colebrook 1977, Bernal 1979, 1981, Chelton et al. 1982, McGowan 1984, 1985, Jiménez-Pérez and Lara-Lara 1988, McGo- wan et al. 1996, Lavaniegos et al. 1998) for the CC region. In all of these studies, highest zooplankton biomass episodes were correlated with low SST. According to our results and those of Filonov et al. (2000), the tropical coast of México is influenced during winter

\section{Temperature ${ }^{\circ} \mathrm{C}$}
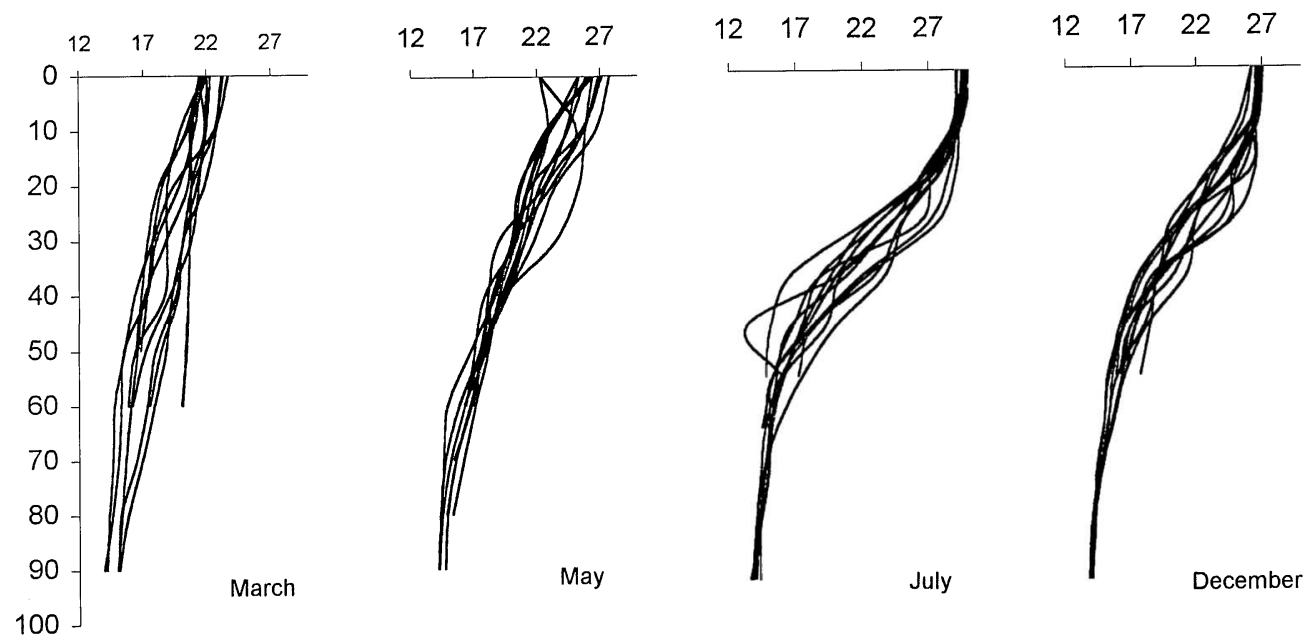

Depth (m)

FIGURE 6. Temperature profiles of the main oceanographic seasons. 
by advective processes related to the CC. These processes promote coastal upwelling systems that enrich the surface layers, a wellknown feature of the CC system (McGowan et al. 1996).

Previous surveys of the zooplankton variability of the CC system showed strong links between zooplankton biomass and advective mesoscale processes (Bernal 1979, 1981, Bernal and McGowan 1981, Chelton et al. 1982, Lavaniegos et al. 1998). Those studies suggest that zooplankton biomass is sensitive to local changes in primary productivity that are due to advective processes, which affect nutrient impact (Roesler and Chelton 1987). Periods of high secondary productivity in the northeastern Pacific Ocean, and particularly in the CC system, occur asynchronically or are episodic, spatially limited events (McGowan et al. 1996). According to Brodeur et al. (1996) the processes that enhance productivity tend to be localized and transient. HernándezTrujillo (1998) stated that month-to-month variation of biomass values is very high in the area of Baja California; this seems to be true also for our study area. The erratic spatial distribution of highly variable biomass values found in our study suggests that the major fluctuations of zooplankton biomass during the survey period are more related to hydrological-physical processes than to strictly biological factors, at least in the holoplankton. Hence, the high month-to-month variability of our data, and particularly the very high isolated values (over $1500 \mathrm{~cm}^{3} / 1000 \mathrm{~m}^{3}$ ), seems to confirm the idea of temporal and spatial patchiness, even in more tropical areas such as our survey area.

The abundance of ichthyoplankton in the same survey area (Franco-Gordo et al. 2001) exhibited a behavior similar to that of the zooplankton biomass in terms of distribution in time and space. Variations in zooplankton abundance can affect larval fish populations in several ways, and a positive correlation is expected when zooplankton is considered as food for fish larvae (McGowan et al. 1996). However, interactions between trophic levels seem to be more complex, and data suggest that a lag of several months occurs between peaks in abundance of zooplankton and fish larvae. In tropical zones, such as the survey area, with a more diverse assemblage of species and different dynamics, it seems reasonable to expect that this lag may be reduced. Lucano-Ramírez (1998) and SantamaríaMiranda and Rojas-Herrera (1995) stated that the reproductive season of some of the commercially relevant species in the area occurs from November to April (winter), perhaps coinciding with increased food availability for their larvae. Mullin and Cass-Clay (1997) noted an overall correlation between the abundance of the larvae of the Pacific hake and zooplankton biomass. Thus, the reproductive strategies of some of the fish species dwelling in the Mexican tropical Pacific appear to be linked to peaks in primary and secondary productivity in these areas.

Some authors have suggested that coastal upwelling processes, besides favoring a local enrichment of the water, could have a relevant role in transporting zooplankters coastward. This effect would increase the chances of larvae reaching shallow coastal, potentially richer, or even nursery zones (Pitts 1999). However, during summer, with a deep thermocline, the riverine or coastal freshwater input in the zone could also produce an enrichment of the coastal systems and promote an increase in zooplankton biomass. Ekman transport during upwelling periods, together with the daytime migration patterns shown by some zooplankton groups (Zaret and Suffern 1976), could result in a differential distribution related to both depth and distance offshore (Pitts 1999).

To reduce sampling bias related to zooplankton migration cycles and emphasize physical, hydrological effects, all of our samples were taken at night and included up to $71 \%$ of the water column. Therefore, the variability of biomass observed in this survey can be attributed to the effect of physical, hydrological conditions rather than to migrational patterns.

Pronounced interannual variability of the distribution of zooplankton biomass has been demonstrated in the CC system (McGowan et al. 1996) and even in transitional areas such as the southern part of the Baja California peninsula (Hernández-Trujillo 1998). Al- 
though a general pattern has been established in our survey area, further studies are needed to refine interpretations of fluctuations in zooplankton biomass in this tropical zone.

\section{ACKNOWLEDGMENTS}

The Universidad de Guadalajara provided financial help to carry out this survey. We are grateful to the crew of the ship $B I P-V$ for their assistance. Ramiro Flores Vargas offered valuable help during sampling activities. Thanks also to the personnel of the Project Demersales.

\section{Literature Cited}

Ahlstrom, E. H., and J. R. Thrailkill. 1963. Plankton volume loss with time of preservation. Calif. Coop. Oceanic Fish. Invest. Rep. 9:57-73.

Badan, A. 1997. La corriente costera de Costa Rica en el Pacífico Mexicano. Monografía No. 3, Unión Geofísica Mexicana.

Baduini, C. L. 1997. Spatial and temporal patterns of zooplankton biomass in Monterey Bay, California, during the 1991$1993 \mathrm{El}$ Niño, and an assessment of the sampling design. Calif. Coop. Oceanic Fish. Invest. Rep. 38:193-199.

Beers, J. R. 1976. Volumetric methods. Pages 56-60 in H. F. Steedman, ed. Zooplankton fixation and preservation. Monogr. Oceanogr. Methodol. 4.

. 1981. Determinación de la biomasa del zooplancton. Pages 133-141 in D. Boltovskoy, ed. Atlas del zooplancton del Atlántico sudoccidental y metodos de trabajo con el zooplancton marino. Pub. Esp. INIDEP, Mar del Plata, Argentina.

Bernal, P. 1979. Large-scale biological events in the California Current. Calif. Coop. Oceanic Fish. Invest. Rep. 20:89-101.

- 1981. A review of the low-frequency response of the pelagic ecosystem in the California Current. Calif. Coop. Oceanic Fish. Invest. Rep. 22:49-62.

Bernal, P., and J. A. McGowan. 1981. Advection and upwelling in the California Current. Pages 381-399 in F. A. Richards, ed. Coastal upwelling. American Geophysical Union, Washington, D.C.

Brinton, E., A. Fleminger, and D. SiegelCausey. 1986. The temperate and tropical planktonic biotas of the Gulf of California. Calif. Coop. Oceanic Fish. Invest. Rep. 27:228-266.

Brodeur, R. D., B. W. Frost, S. R. Hare, R. C. Francis, and W. J. Ingraham. 1996. Interannual variations in zooplankton biomass in the Gulf of Alaska, and covariation with California Current biomass. Calif. Coop. Oceanic Fish. Invest. Rep. 37:8099.

Chelton, D. B., P. A. Bernal, and J. A McGowan. 1982. Large scale interannual physical and biological interaction in the California Current. J. Mar. Res. 40:10951125.

Colebrook, J. M. 1977. Annual fluctuations in biomass of taxonomic groups of zooplankton in the California Current, 195559. Fish. Bull. 72:357-368.

Denman, K. L., and T. M. Powell. 1984. Effects of physical processes on planktonic ecosystems in the coastal ocean. Oceanogr. Mar. Biol. Annu. Rev. 22:125-168.

Filonov, A., I. E. Tereshchenko, C. O. Monson, M. E. González-Ruelas, and E. Godínez-Domínguez. 2000. Variabilidad estacional de los campos de temperatura y salinidad en la zona costera de los estados de Jalisco y Colima, México. Cienc. Mar. 26:303-321.

Franco-Gordo, C., E. Suárez-Morales, E. Godínez-Domínguez, and R. Flores-Vargas. 2001. A seasonal survey of the fish larvae community of the central Pacific coast of Mexico. Bull. Mar. Sci. (in press).

Godínez-Domínguez, E., and G. GonzálezSansón. 1998. Variación de los patrones de distribución batimétrica de la fauna macrobentónica en la plataforma continental de Jalisco y Colima, México. Cienc. Mar. 24:337-351.

Griffiths, F. B., B. K. Fleminger, and M. Vannucci. 1976. Shipboard and curating techniques. Pages 17-31 in H. F. Steedman, ed. Zooplankton fixation and preservation. Monogr. Oceanogr. Methodol. 4. 
Haury, I. R., J. A. McGowan, and P. H. Wibe. 1978. Patterns and processes in the time-space scales of plankton distributions. Pages 277-337 in J. Steele, ed. Spatial pattern in plankton communities. Plenum Press, New York.

Heinrich, A. K. 1962. The life histories of plankton animals and seasonal cycles of plankton communities in the oceans. Cons. Int. Explor. Mer 27:15-24.

Hernández-Trujillo, S. 1998. La comunidad de copépodos pelágicos en la costa del $\mathrm{Pa}$ cifico de la Península de Baja California (1984-1989). Ph.D. diss., Universidad Nacional Autónoma de México, México, D.F., México.

Jiménez-Pérez, C., and J. R. Lara-Lara. 1988. Zooplankton biomass and copepod community structure in the Gulf of California during the 1982-1983 El Niño event. Calif. Coop. Oceanic Fish. Invest. Rep. 29:122-128.

Lavaniegos, B., J. Gómez-Gutiérrez, J. R. Lara-Lara, and S. Hernández-Vázquez. 1998. Long-term changes in zooplankton volumes in the California Current System-the Baja California region. Mar. Ecol. Prog. Ser. 169:55-64.

Longhurst, A. 1998. Ecological geography of the sea. Academic Press, San Diego, California.

Lucano-Ramírez, G. 1998. Ciclo reproductivo de Lutjanus peru (Nichols \& Murphy, 1922) (Pisces: Lutjanidae) en la costa sur de Jalisco. M.S. thesis, Universidad Nacional Autónoma de México, México, D.F., México.

McGowan, J. A. 1984. The California El Niño, 1982. Oceanus 27 (2): 48-51.

- 1985. El Niño 1983 in the Southern California Bight. Pages 166-184 in W. S. Wooster and D. L. Fluharty, eds. El Niño north-Niño effects in the eastern subarctic Pacific Ocean. Washington Sea Grant Program, Seattle.

McGowan, J. A., D. B. Chelton, and A. Conversi. 1996. Plankton patterns, climate, and change in the California Current. Calif. Coop. Oceanic Fish. Invest. Rep. 37:45-68.
Mullin, M. M., and S. L. Cass-Clay. 1997. Vertical distributions of zooplankton and larvae of the Pacific hake (Whiting), Merluccius productus, in the California Current system. Calif. Coop. Oceanic Fish. Invest. Rep. 38:127-136.

Owen, R. W. 1981. Fronts and eddies in the sea: Mechanisms, interactions and biological effects. Pages 197-233 in A. R. Longhurst, ed. Analysis of marine ecosystems. Academic Press, London.

Pacheco-Sandoval, P. 1991. Pacífico Tropical Mexicano. Cabo Corrientes a la frontera con Guatemala. Corrientes y circulación. Pages 162-168 in G. De la Lanza-Espino, ed. Oceanografía de los mares mexicanos. AGT Editor, México.

Pitts, P. A. 1999. Effects of summer upwelling on the abundance and vertical distribution of fish and crustacean larvae off central Florida's Atlantic coast. J. Exp. Mar. Biol. Ecol. 235:135-146.

Roesler, C. S., and D. B. Chelton. 1987. Zooplankton variability in the California Current, 1951-1982. Calif. Coop. Oceanic Fish. Invest. Rep. 28:59-96.

Santamaría-Miranda, A., and A. A. RojasHerrera. 1995. Análisis de la variación morfológica del flamenco, Lutjanus guttatus (Steindachner, 1869) (Pisces: Lutjanidae) en el litoral de Acapulco, Gro., México 1993-1994. Memorias XII Congreso Nacional de Zoología, Morelia, Michoacan.

Smith, P. E., and S. L. Richardson. 1979. Standard techniques for pelagic fish and larvae survey. FAO Fish. Tech. Pap. 175:1-100.

Smith, K. A., M. T. Gibbs, J. H. Middleton, and I. M. Suthers. 1999. Short term variability in larval fish assemblages of the Sydney shelf: Tracers of hydrographic variability. Mar. Ecol. Prog. Ser. 178:1-15.

Suárez-Morales, E., and R. Gasca. 1994. Zooplankton biomass fluctuations in a Mexican Caribbean bay (Bahía de la Ascensión) during a year cycle. Caribb. J. Sci. 30:116-123.

Tunell, R. C., C. J. Pride, P. Ziveri, F. Muller-Karger, C. Sancetta, and D. Murray. 
1996. Plankton response to physical forcing in the Gulf of California. J. Plankton Res. 18 (11): 2017-2026.

Wyrtki, K. 1965. Surface currents of the eastern tropical Pacific Ocean. Inter-Am. Trop. Tuna Comm. Bull. 9 (5): 271-304.
Zar, J. H. 1996. Biostatistical analysis, 3rd ed. Prentice Hall, New Jersey.

Zaret, T. M., and J. S. Suffern. 1976. Vertical migration in zooplankton as a predator avoidance mechanism. Limnol. Oceanogr. 21:804-813. 